\title{
THE ROLE OF THE NATURAL ANTIOXIDANTS IN THE OXIHAEMOGLOBIN OXIDATION AND THE DIMINUTION OF NITRITE CONCENTRATION
}

\author{
Maria Gonța \\ Department of Ecological and Industrial Chemistry, State University of Moldova, 60 Mateevici, Chisinau, Republic of Moldova, \\ Tel.: 57-75-53,E-mail:mvgonta@yahoo.com
}

\begin{abstract}
The paper includes the study of the inhibition of the process of methemoglobinization at oxidation with nitrites in the presence of sodium dihydroxyfumarate $\left(\mathrm{DFH}_{3} \mathrm{Na}\right)$ and resveratrol $\left(3,4^{\prime}, 5\right.$-trihydroxystilben). The experimental study was carried out by treatment of the erythrocyte mass by hemolysis and exposure to nitrite. The kinetic investigations were carried out in following conditions: $[$ Resv $]=\left(5 \cdot 10^{-5}-1 \cdot 10^{-3}\right) \mathrm{mol} / 1,\left[\mathrm{DFH}_{3} \mathrm{Na}\right]=1 \cdot 10^{-6}-5 \cdot 10^{-6} \mathrm{~mol} / 1 ;\left[\mathrm{HbO}_{2}\right]=1 \cdot 10^{-3}$ $\mathrm{mol} / \mathrm{l} ; \mathrm{pH} \mathrm{7,1;t}=37^{\circ} \mathrm{C}$. The rate of transformation of $\mathrm{HbO}_{2}$ in the presence of resveratrol and $\mathrm{DFH}_{3} \mathrm{Na}$ was calculated from kinetic curves of consumption of the substrate and formation of MetHb obtained spectrophotometrically $\left(\lambda_{\max }=\right.$ $540 \mathrm{~nm}$ for $\mathrm{HbO}_{2}$ and $\lambda_{\max }=630$ for MetHb). It has been found out that the introduction of resveratrol and $\mathrm{DFH}_{3} \mathrm{Na}^{\max }$ the system $\mathrm{HbO}_{2}-\mathrm{NO}_{2}^{-}$causes the decrease of the autooxidation factor $\varphi_{\text {DFH3Na }}$ approximately by $1.1-2.5$ times and $\varphi_{\text {resveratrol }}$ by $1.1-1.7$ times. The time of achievement of the maximum rate of oxidation of $\mathrm{HbO}_{2} \mathrm{~d} \zeta / \mathrm{d} \tau$ (where $\zeta$ is the rate of transformation of $\mathrm{HbO}_{2}$ in $\mathrm{MetHb}$ ) increases while the phase of fast oxidation of $\mathrm{HbO}_{2}$ decreases with increase of content of inhibitors. The process of interaction of nitrites with reducers (such as $\mathrm{DFH}_{4}, \mathrm{DFH}_{3} \mathrm{Na}$, resveratrol and $(+)$-catechine) was carried out as well. It has been established that degree of diminishing of the concentration of nitrites in the system $\mathrm{RedH}_{2}-\mathrm{NO}_{2}-$ decreases as follows: $\mathrm{DFH}_{4}<\mathrm{DFH}_{3} \mathrm{Na}<\mathrm{Resv}<(+)$ Catechol.
\end{abstract}

Keywords: nitrite, haemoglobin, inhibitor of methemoglobinization.

\section{INTRODUCTION}

In the specialized literature there are described groups of compounds that lead to MetHb formation (among them, different xenobiotics). The nitrates, the nitrites and nitric oxides play an important role in the MetHb formation; they penetrate in the human body via various ways: during the ingestion (food and water) and inhalation. The nitrates and the nitrites are indispensably joined with each other in the natural circuit of the nitrogen, but due to the chemical activity of the nitrite ion, their concentration in the environment is insignificant. Thus, the first stage of intoxication with nitrates is their reduction in nitrites. In all living beings, simultaneously with the common process of $\mathrm{O}_{2}$ elimination, there occurs the self oxidation of $\mathrm{HbO}_{2}$ in $\mathrm{MetHb}$ :

$$
\mathrm{HbO}_{2} \rightarrow \mathrm{MetHb}+\mathrm{O}_{2} \cdot
$$

From the above reaction, we can observe that the radical of super oxide anion, with pragmatical properties is generated $\left(\mathrm{O}_{2}^{-}\right)$. This radical was detected in $\mathrm{HbO}_{2}-\mathrm{NaNO}_{2}$ system, via the RMN method [1].

During the process of $\mathrm{HbO}_{2}$ oxidation with $\mathrm{NO}_{2}^{-}$, the oxygen from the haemoglobin molecule that appears as an auto catalyst in this process plays a great role. The authors of this work [2] suppose that after the process of oxidereduction at the interaction of $\mathrm{NO}_{2}^{-}$with $\mathrm{O}_{2} \cdot$ - takes place the generation of nitrate oxide. Such a direction of the process is assured by the oxide-reducing potentials of $\mathrm{NO}_{2}^{-}$and $\mathrm{O}_{2}^{-}$, accordingly $+0,99$ and $-0,33 \mathrm{~V}$. The $\mathrm{O}_{2} \cdot$ radical is not a direct oxidant of $\mathrm{HbO}_{2}$, but it is compulsory in the process of autocatalysis.

Another important factor in the $\mathrm{HbO}_{2}$ oxidation mechanism is the formation of $\mathrm{NO}_{2}{ }^{\bullet}$ at the initial stage of the oxidation process. The formation of this radical in the system was established by the use of amines (aniline), which imbibes the process of $\mathrm{HbO}_{2}$ oxidation, due to the formation of N-nitrosamines with $\mathrm{NO}_{2}^{-}[3]$.

An important intermediary of the $\mathrm{HbO}_{2}$ oxidation process with $\mathrm{NO}_{2}^{-}$is $\mathrm{H}_{2} \mathrm{O}_{2}$, which forms as a result of $\mathrm{O}_{2}{ }^{-}$ dismutation [2]. We established that $\mathrm{H}_{2} \mathrm{O}_{2}$ influence upon the $\mathrm{HbO}_{2}$ oxidation reaction with $\mathrm{NO}_{2}^{-}$depends on the initial concentrations of $\left[\mathrm{NO}_{2}^{-}\right]_{0}$ and $\left[\mathrm{H}_{2} \mathrm{O}_{2}\right]_{0}$.

Knowing the mechanisms of the reactions between haemoglobin and different methemoglobinisants helps to elaborate methods of inhibition against haemoglobin oxidation.

$\mathrm{HbO}_{2}$ oxidation with nitrites is being studied as a 2-stage process [4]: the slow process (lag period) and the fast process, (auto catalyst). The kinetic curves have a peculiar S-shape. There should be mentioned that the process of oxidation of the oxygenated form of $\mathrm{HbO}_{2}$ and $\mathrm{Hb}$ with nitrites is different.

In order to decrease the degree of $\mathrm{HbO}_{2}$ oxidation and diminish the concentration of oxidative particles that form in various systems it is necessary to use different antioxidants, especially natural ones. 


\section{The antioxidant activity of polyphenols}

The polyphenols are characterized by their antioxidant activity and they can be used as well to reduce the oxidational degree of different substances.

The flavonoids constitute a large class of compounds present in plants, which contain a certain number of hydroxyl phenolic groups attached to the annular structure, endowing reducing properties. The antioxidant activity of phenols is determined by the presence of hydroxyl groups in B ring, in the positions 3' and 4' and in a lesser degree, by the hydroxyl group from B ring, in the position 4'. The phenols, especially the catehine, quercitin, kaemferol and their glycosides, are constituents of the green and black tea [5] and red wine [5]. The diets rich in fruits, vegetables and grapes are recommended against heart diseases accompanying various forms of cancer [7,8], methemoglobinemy, have antiinflammatory and antimutagene effects [9] etc. These protecting effects have been attributed to the present antioxidants that include flavonoids, carotids and the vitamins $\mathrm{C}$ and $\mathrm{B}$.

The researches performed in vitro established the antioxidant potential of the polyphenols as the parameter that determined the capture capacity of the free radicals, such as super oxide radicals, the singlet oxygen, hydroxyl radicals, peroxyl radicals, nitric monoxide and the peroxinitrite (they cause different pathologies). The chemical structures that contribute to the antioxidant activity of the polyphenols, including the neighbouring dihidroxi- or trihidroxi-structure, can cellar the ions o metal through the formation of complex and prevent the generation of free radicals. This structure also allows delocalizing the electrons, conferring high reactivity for destruction of free radicals.

The majority of polyphenolic constituents from the food products (flavonols - such as quercitin and kaempherol, flavones - such as luteolin, flavonols - such as catechin, antocynidins for instance, cyanidin and malvidin and their glycosides) present major efficiency, in comparison with the nutrient antioxidants: vitamins $\mathrm{C}, \mathrm{E}, \beta$-carotene, that are easily absorbed in the intestine [10].

Antocynidins and catechines have been tested in vitro for their inhibitional influence upon the cyclooxigenaze enzymes (COX) that provoke the multiplication of cancerogen cells and also upon the proliferation of cancer cells in human beings [5]. We established that cyanidine has the strongest inhibitory effect of the COX enzymes and it has hydroxyl groups 3',4' in B ring. The inhibitory activity decreased in the case of delphinidine and pelargonidine, that have 3', 4', 5'-trihidroxilic and 4'-hidroxilic groups in B ring, accordingly. From the point of view of the liaison between the structure and the activity, the number and the position of hydroxyl groups in auto cyanides B ring influence the inhibitory activity of these compounds. For catechine cis-, trans-isomery, epimerisation did not influence greatly the inhibitory activity on COX enzyme, but the presence of galloyl groups in catechine structure influenced more their inhibitory activity on the COX enzymes. Based on the obtained results during the inhibition of proliferation of cancer cells under the action of antocyanidins and catechines, we established that the degree of inhibition is higher for the galloyl derivatives of catechines [5] (gallocatechine - 95\%, epigallocatechine $-100 \%$ and gallocatechingalate - 97\%), but for antocyanidins, it represents almost $75 \%$.

The degree of polymerisation has a greater influence on the inhibitory properties of the polyphenols and it augments together with the galloylation. The polyphenolic fractions extracted from the grapes with a different degree of polymerisation had a different antioxidant/antiradical and antiproliferative effect [6]. The polyphenolic solutions extracted from the grapes have been divided into 2 fractions having a different degree of polymerisation, with RPHPLC. The antioxidant/antiradical activity determined via the DPPH test for the polyphenolic fraction from the grapes, composed of small, was higher than the fraction which included procyanide flavonols and oligomers with a greater molecular mass. Catherine A Rice-Evans et alt. [10] have studied the total antioxidant activity (TAA) and the antioxidant activity equal to Trolox (AAET) for the polyphenols that are contained in the green tea and red wine. AAET measures the concentration of the Trolox solution $(\mathrm{mM})$ with a potential antioxidant equivalent at a standard concentration of the compound subjected to the research. The authors came to the conclusion that the antioxidant activity of the polyphenolic constituents of the green tea (Fig.1) in correlation with their content, according to their order of antioxidant activity, is: epigallocatechine $(34 \%) \approx$ epigallocatechingalate $(32 \%)>>$ epicatehingallate $(7 \%) \approx$ epicatechine $(6 \%)>$ catechine $(1 \%)[10]$.

Through radio lithium generation of oxygen species in presence of different catechines, that are active constituents of the tea, we established that the DNA harm caused by these reactive particles, decreases at least in the presence of EGCG [11]. Thus, $66 \%$ from the antioxidant activity of the green tea is determined by epigallocatechine and epigallocatechinegallate, which corresponds to the content of these compounds in the green tea $(20,44 \%$ from $26,71 \%$ of the total number of polyphenols).

Based on the study of the total average antioxidant activity of the red wine, we established that $54,76 \%$ is determined by catechine and epicatechine contribution that represent almost 63,54\% from the phenol constituents (191 and $82 \mathrm{mg} / \mathrm{l}$ accordingly) [10]. 

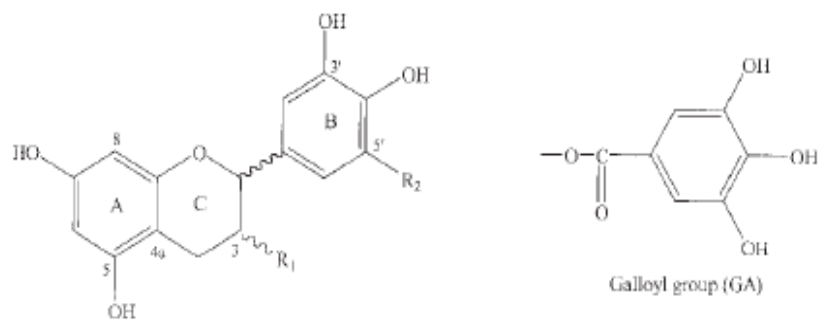

Fig. 1. The chemical structure of the catechines present in tea and in wine [5]. Catechine- $\left(\mathrm{R}_{1}-\mathrm{OH}, \mathrm{R}_{2}-\mathrm{H}\right)$, gallocatechine- $\left(R_{1}-O H, R_{2}-O H\right)$, catechingalate $\left(R_{1}-G A, R_{2}-H\right)$, gallocatechingalate $\left(R_{1}-G A, R_{2}-O H\right)$.

In various systems, the free radicals can form as a result of peroxide decomposition in presence of different metals: $\mathrm{Fe}^{2+}, \mathrm{Cu}^{2+}, \mathrm{Cr}^{3+}$ etc. As a result of $\mathrm{H}_{2} \mathrm{O}_{2}$ reduction through the Fenton reaction in presence of $\mathrm{Cr}^{3+}$ (which is toxic and causes genotoxicity), the $\mathrm{OH}^{\cdot}$ radical is being formed:

$$
\mathrm{Cr}(\mathrm{III})+\mathrm{H}_{2} \mathrm{O}_{2} \rightarrow \mathrm{Cr}(\mathrm{IV})+\mathrm{OH}^{\cdot}+\mathrm{OH}^{-}
$$

The hydroxyl radical formed in vivo produces oxidative harm to DNA, with the formation of 8-hydroxy-2deoxyguanosine $(8-\mathrm{OH}-\mathrm{dG})$ that appears in this process as a biomarker [12]. Based on the study results, Silvia LopezBurillo et al. [12] established that the antioxidants inhibit the oxidative processes of DNA. Among the polyphenols studied in [12], the highest inhibitory effect is presented by (-)-epigallcatechine-3-gallate (EGCG) in concentration of 1 $\mu \mathrm{M}$ or more, which reduces the $8-\mathrm{OH}-\mathrm{dG}$ formation. Tea catechines can form stable compounds with $\mathrm{Cu}$ (II) and $\mathrm{Cr}$ (III) and as a result, $\mathrm{OH}^{*}$ radicals are generated [13]. But it was established that in the case of EGCG $\mathrm{OH}^{*}$ radicals are split up by the gallate group present in the complex and thus, the prooxidant effect of this compound is not manifested [14].

The green and black tea can inhibit lipoproteins' oxidation induced by $\mathrm{Cu}^{2+}$ [13], thus, it contributes to the prevention of arteriosclerosis and other heart diseases. The inhibition of this very process is determined by the fact that polyphenols can cellar the metals and decrease the concentration of active forms of the oxygen, which in its turn takes part at the protein oxidation.

\section{MATERIALS AND METHODS}

An inhibitor that was used in the, $\mathrm{HbO}_{2}-\mathrm{NO}_{2}^{-}$system is sodium dihydroxifumarole $\left(\mathrm{DFH}_{3} \mathrm{Na}\right)$. In order to establish the degree of inhibition, we studied the kinetic of the process of $\mathrm{HbO}_{2}\left(\lambda_{\max }=540 \mathrm{~nm}\right)$ consumption and MetHb $\left(\lambda_{\max }=630 \mathrm{~nm}\right)$ accumulation [15]. We counted the degree of transformation $(\eta)$ after $\mathrm{HbO}_{2}$ consumption, using the relation $\eta=D_{0}-D_{\tau} / D_{0}-D_{\infty}$ and the degree of MetHb formation according to the relation $\eta=D_{\tau} / D_{\infty}$. In concordance with the kinetic curves under the S-shape we measured the speed of the reaction as a derivative of the degree of conversion in time $(\mathrm{d} \eta / \mathrm{d} \tau)$ [16].

The interaction of the sodium dihydroxifumarole $\left(\mathrm{DFH}_{3} \mathrm{Na}\right)$ and polyphenols with the nitrite ion was studied according to the variation of the nitrite concentrations in system with the use of Griess reagent [17]. We studied the influence of the reducer concentration on the speed of nitrite transformation reaction. $\mathrm{DFH}_{3} \mathrm{Na}_{\text {concentration has been }}$ varied within the following interval: $0-1 \cdot 10^{-3} \mathrm{M}\left(\mathrm{C}_{\text {DFHNa }}^{1}=0 \mathrm{M}, \mathrm{C}_{\text {DFHNa }}^{2}=1 \cdot 10^{-4} \mathrm{M}, \mathrm{C}_{\text {DFHNa }}^{3}=5 \cdot 10^{-4} \mathrm{M}, \mathrm{C}^{4}{ }_{\mathrm{DFHNa}}=1 \cdot 10^{-3}\right.$ $\mathrm{M})$. The reaction took place in the citrat-phosphate solution buffer with $\mathrm{pH} 2,6 \mathrm{at} \mathrm{t}=37^{\circ} \mathrm{C}$. the other reducers have been studied in the same interval of concentrations.

During the experiments, we used various reagents: $(+)$ catechine (Fluka, 98\%, HPLC), $\mathrm{DFH}_{3} \mathrm{Na}, \mathrm{DFH}_{4}($ Aldrich, 98\%), resveratrol (Fluka, 98\%, HPLC). There had been used the erythrocytes mass, collected from healthy donors, afterwards subjected to haemolysis during 18-20 hours.

\section{RESULTS OF THE EXPERIENCES}

The influence of sodium dihydroxifumarole on the $\mathrm{HbO}_{2}$ oxidation with $\mathrm{NO}_{2}^{-}$

The formation of the MetHb in $\mathrm{HbO}_{2}-\mathrm{NO}_{2}^{-}$system in presence of $\mathrm{DFH} 3 \mathrm{Na}$ at $\mathrm{t}=20^{\circ} \mathrm{C}, \mathrm{pH} 7.2$ (phosphate solution buffer), $\left[\mathrm{HbO}_{2}\right]_{0}=5 \cdot 10^{-5} \mathrm{~mol} / 1$ depending on various concentrations of $\mathrm{DFH}_{3} \mathrm{Na}$ is presented in Fig.2. From the data of the experiments shown in Fig.2., at the variation of $\left[\mathrm{DFH}_{3} \mathrm{Na}\right]_{0}\left(\mathrm{C}_{\mathrm{DFH}_{3} \mathrm{Na}}^{1}=0 ; \mathrm{C}_{\mathrm{DFH}_{3} \mathrm{Na}}^{2}=2 \cdot 10^{-6} \mathrm{~mol}_{1} / \mathrm{C}^{3}{ }_{\mathrm{DFH}_{3} \mathrm{Na}}=\right.$ $\left.3 \cdot 10^{-6} \mathrm{~mol} / 1 ; \mathrm{C}_{\mathrm{DFH}_{3} \mathrm{Na}}^{4}=4 \cdot 10^{-6} \mathrm{~mol} / 1 ; \mathrm{C}_{\mathrm{DFH}_{3} \mathrm{Na}}^{5}=5 \cdot 10^{-6} \mathrm{~mol} / 1\right)$ the maximum concentration of MetHb is reached within $\mathrm{t}=30$ $\min$ for $\mathrm{C}_{\mathrm{DFH}}^{1} \mathrm{Na}_{3}$ and increases till $\mathrm{t} \approx 60 \mathrm{~min}^{\text {forC }}{ }_{\mathrm{DFH}_{3} \mathrm{Na}}$. 


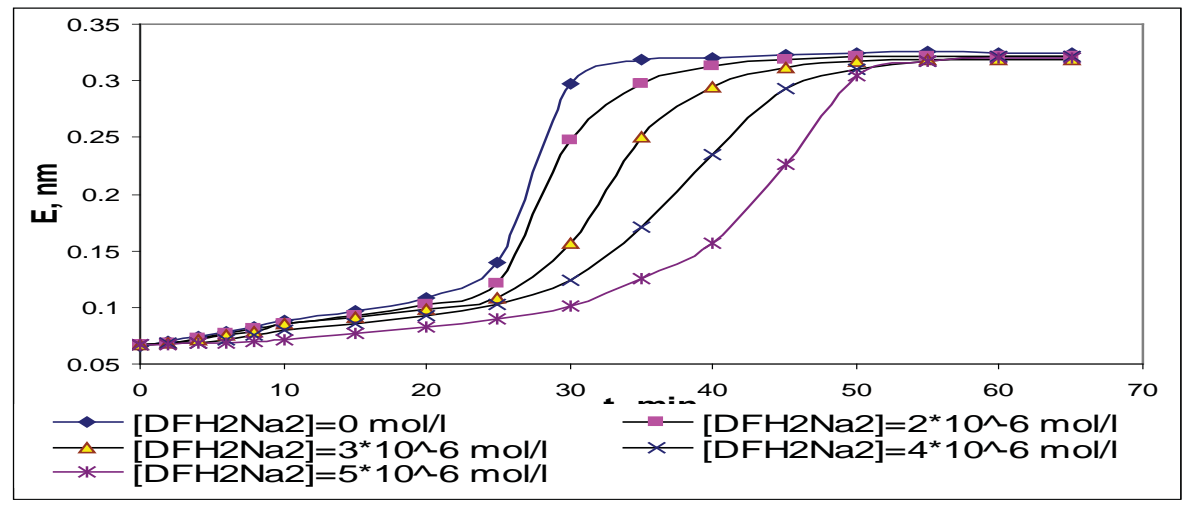

Fig. 2. The kinetic curves of MetHb formation in the $\mathrm{HbO}_{2}-\mathrm{NO}_{2}^{-}-\mathrm{DFH}_{2} \mathrm{Na}_{2}$ system, at the variation of $\mathrm{DFH}_{2} \mathrm{Na}_{2}$ concentration, phosphate solution buffer, $\mathrm{pH}=7,2, \mathrm{t}=21^{\circ} \mathrm{C}, \lambda=630 \mathrm{~nm},\left[\mathrm{HbO}_{2}\right]=5^{*} 10^{\wedge}-5 \mathrm{~mol} / 1,\left[\mathrm{NO}_{2}{ }^{-}\right]=5^{*} 10^{\wedge}$ $-4 \mathrm{~mol} / \mathrm{l}$.

At the oxidation of $\mathrm{HbO}_{2}$ with $\mathrm{NO}_{2}^{-}$in presence of AAs the speed of the process after the curvature point in $\mathrm{f}\left([\mathrm{AAs}]_{0}\right)$ varies in a lesser degree in comparison with the oxidation of $\mathrm{HbO}_{2}$ with $\mathrm{NO}_{2}$ - in presence of $\mathrm{DFH} \mathrm{Na}_{3}$, depending on its concentration. The influence upon the period of induction is peculiar for AAs. Contrary to this, the duration period of induction for the system with $\mathrm{DFH}_{3} \mathrm{Na}$ is shorter, depending on its concentration, but the speed suffers a lot of changes after the curvature point of the autocatalytic process (Fig.2.)

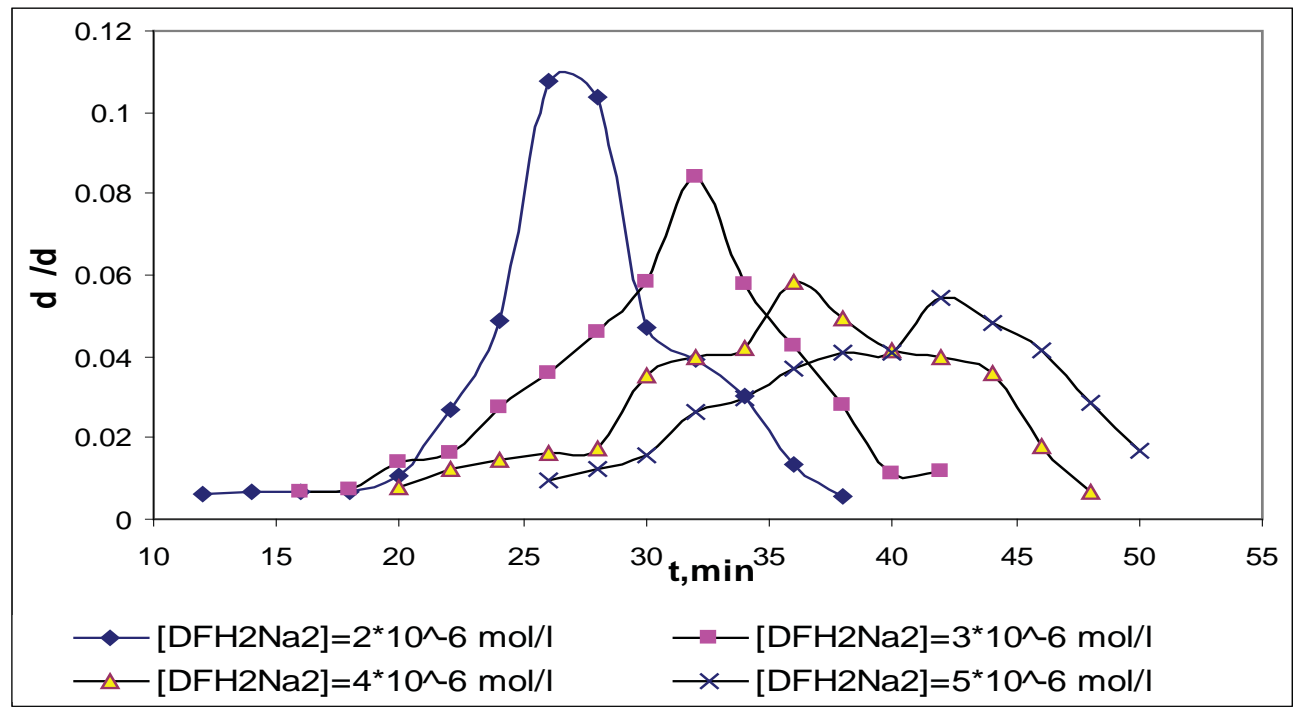

Fig.3. Speed variation $(\mathrm{d} \eta / \mathrm{d} \tau)$ depending on the time $\mathrm{HbO}_{2}-\mathrm{NO}_{2}^{-}-\mathrm{DFH}_{2} \mathrm{Na}_{2}$ system at variation of $\mathrm{DFH}_{2} \mathrm{Na}_{2}$ concentration, phosphate solution buffer, $\mathrm{pH}=7,2, \mathrm{t}=21^{\circ} \mathrm{C}, \lambda=540 \mathrm{~nm},\left[\mathrm{NO}_{2}^{-}\right]=5^{*} 10^{\wedge}-4 \mathrm{~mol} / 1,\left[\mathrm{HbO}_{2}\right]=$ $5 * 10^{\wedge}-5 \mathrm{~mol} / \mathrm{l}$.

Speed variation $(\mathrm{d} \eta / \mathrm{d} \tau)$ depending on time, measured on the basis of data obtained at $\lambda=540 \mathrm{~nm}$ and $\lambda=630 \mathrm{~nm}$, depends on $\left[\mathrm{DFH}_{3} \mathrm{Na}\right]_{0}$. The maximum variation of the speed $(\mathrm{d} \eta / \mathrm{d} \tau)$ of MetHb formation in $\mathrm{f}(\eta)$ with the increase of $\left[\mathrm{DFH}_{3} \mathrm{Na}\right]_{0}$, reduces. We established that the position of the maximum of kinetic curve $\mathrm{d} \eta / \mathrm{d} \tau$ changes insignificantly depending on $\eta$ and corresponds to the interval $\eta=(0,5-0,7)$.

The change of maximum $\mathrm{d} \eta / \mathrm{d} \tau=\mathrm{f}(\eta)$ towards the direction of smaller values of $\eta$ for smaller concentrations of $\mathrm{DFH}_{3} \mathrm{Na}$, is determined by the presence in the reaction medium of $\mathrm{NO}_{2}$ radicals, with a higher concentration, which assures a greater contribution in the stage of process division, with the participation of this radical and with the reaching of the maximum speed. We observed that $\mathrm{d} \eta / \mathrm{d} \tau$ size depends on $\left[\mathrm{DFH}_{3} \mathrm{Na}\right]_{0}$ and increases when $\left[\mathrm{DFH} \mathrm{Na}_{0} \mathrm{decreases}\right.$ At $\mathrm{C}_{\mathrm{DFH}_{3} \mathrm{Na}}^{5}$ we obtain $\mathrm{d} \eta / \mathrm{d} \tau$ almost twice smaller than in the case of $\mathrm{C}_{\mathrm{DFH}_{3} \mathrm{Na}}^{2}$.

The angular coefficient of $\sqrt{ } \eta$ dependence on $\tau$ (factor of de auto acceleration $\varphi=\operatorname{tg} \alpha$ ) decreases when the concentration of the inhibitor increases. We can suppose that the catalyst concentration $\left(\mathrm{H}_{2} \mathrm{O}_{2}\right)$, in the autocatalytic process diminishes when the $\mathrm{DFH}_{3} \mathrm{Na}$ concentration increases, because the acceleration factor $\varphi$ reduces, when $\mathrm{DFH}_{3} \mathrm{Na}$ augments. Thus, we established that this inhibitor influence upon the division of the chain in $\mathrm{HbO}_{2}$ oxidation, decreasing the speed of the auto acceleration process in the reactant medium. 
The introduction in the $\mathrm{HbO}_{2}-\mathrm{NO}_{2}^{-}-\mathrm{DFH}_{3} \mathrm{Na}$ system of $\mathrm{H}_{2} \mathrm{O}_{2}$ leads to the decrease of the inducing period from $25 \mathrm{~min}$ to $\approx 7 \mathrm{~min}$ [18]. If we compare the data of the experiment concerning the speed variation in the systems $\mathrm{HbO}_{2}$ $-\mathrm{NO}_{2}^{-}-\mathrm{DFH}_{3} \mathrm{Na}$ (Fig.3) and $\mathrm{HbO}_{2}-\mathrm{NO}_{2}^{-}-\mathrm{DFH}_{3} \mathrm{Na}-\mathrm{H}_{2} \mathrm{O}_{2}$, we will observe that the maximum variation of the speed in the system without $\mathrm{H}_{2} \mathrm{O}_{2}$ occurs at $\tau=25 \mathrm{~min}$, for $\left[\mathrm{DFH}_{3} \mathrm{Na}\right]=2 \cdot 10^{-6} \mathrm{~mol} / \mathrm{l}$, and in presence of $\left[\mathrm{H}_{2} \mathrm{O}_{2}\right]=5 \cdot 10^{-5} \mathrm{~mol} / 1$, fro the same concentration of the reducer- at $\tau=7 \mathrm{~min}$. The peroxide can interact with $\mathrm{NO}_{2}^{-}(3$ reaction $)$ and thus, there is formed the $\mathrm{NO}_{2} \cdot$ radical that keeps carrying the process.

$$
\mathrm{H}_{2} \mathrm{O}_{2}+\mathrm{NO}_{2}^{-}+\mathrm{H}^{+} \rightarrow \mathrm{NO}_{2}+\mathrm{H}_{2} \mathrm{O}+\mathrm{HO}^{\cdot}
$$

Simultaneously with $\mathrm{NO}_{2} \cdot$ radical there forms $\mathrm{HO}^{\cdot}$ radical that further participates in carrying of the reaction and in augmentation of the $\mathrm{NO}_{2} \cdot$ radical:

$$
\mathrm{HO}^{\cdot}+\mathrm{NO}_{2}^{-} \rightarrow \mathrm{NO}_{2}{ }^{-}+\mathrm{OH}^{-}
$$

In presence of the inhibitor, together with the increase of its concentration, the speed of $\mathrm{HbO}_{2}$ oxidation reduces. The maximum variation of $\mathrm{d} \eta / \mathrm{d} \tau=0,18$ speed for $\left[\mathrm{DFH}_{3} \mathrm{Na}\right]_{0}=2 \cdot 10^{-6} \mathrm{~mol} / 1$ and it decreases up to 0,06 for $\left[\mathrm{DFH} \mathrm{Na}_{3}\right.$ $=5 \cdot 10^{-6} \mathrm{~mol} / \mathrm{l}$ (Fig. 3). The speed of MetHb formation increases in presence of $\mathrm{H}_{2} \mathrm{O}_{2}$ due to the augmentation of the concentration of $\mathrm{NO}_{2}{ }^{-}$radical, that forms additionally to the interaction of $\mathrm{H}_{2} \mathrm{O}_{2}$ with $\mathrm{NO}_{2}^{-}$and which is an oxidation agent of $\mathrm{Fe}^{2+}$ in $\mathrm{Fe}^{3+}$ from haem:

$$
\mathrm{HbO}_{2}+\mathrm{NO}_{2}^{\cdot} \rightarrow \mathrm{MetHb}+\mathrm{O}_{2} \mathrm{NOO}^{-}
$$

The action mechanism of the inhibitor is based on its interaction with $\mathrm{OH}^{\bullet}$ radical that produces after the reaction (3) of more stable particles production [19]. The effect of inhibition will depend on the report of speed constants $\mathrm{k}_{1} / \mathrm{k}_{2}$, in which $\mathrm{k}_{1}$ is the speed constant at the interaction of $\mathrm{OH}^{\circ}$ - radicals with the inhibitor, while $\mathrm{k}_{2}$ - speed constant of the reaction between $\mathrm{OH}^{*}$ and the nitrite ion ( $4^{\text {th }}$ reaction). In the case when $\mathrm{k}_{1} / \mathrm{k}_{2}>1$, we obtain the effect of inhibition, i.e. the speed of the process that leads to $\mathrm{Fe}^{2+}$ oxidation in $\mathrm{Fe}^{3+}$ is lower than the speed generating radical oxidative particles, because these particles further interact with the inhibitor, not with the substrate. Based on the results presented in Fig.2., we consider that $\mathrm{DFH}_{3} \mathrm{Na}$ can interact with both $\mathrm{OH}^{\cdot}$ radical and $\mathrm{HO}_{2} \cdot$ radical, which form at the initial stage. Greater the concentration of the inhibitor, lower is the acceleration speed, as in this process the concentration of the peroxide has the role of catalyst and $\left[\mathrm{HO}_{2}{ }^{-}\right]$decreases. The speed of $\mathrm{HbO}_{2}$ oxidation process decreases due to the reducing of $\left[\mathrm{NO}_{2}{ }^{\circ}\right]$ after the reaction (4).

The effect of nitrite reduction with $\mathrm{DFH}_{3} \mathrm{Na}$ and $\mathrm{DFH}_{4}$

From the obtained data (Tab.1) we established that $\mathrm{DFH}_{3} \mathrm{Na}$ the nitrate concentration decreases in the system and the speed of nitrate consumption is greater when DFH3Na concentration augments.

The effect of nitrite reduction with $\mathrm{DFH}_{3} \mathrm{Na}$ at $\mathrm{pH} 2,6 ; \mathrm{t}=37^{\circ} \mathrm{C},\left[\mathrm{NO}_{2}^{-}\right]_{0}=1 \cdot 10^{-4} \mathrm{M}$

Table 1

\begin{tabular}{|c|c|c|c|c|}
\hline Nr. & {$\left[\mathrm{DFH}_{3} \mathrm{Na}\right]_{0}, 10^{-4}, \mathrm{M}$} & $\mathrm{W}_{\text {iniț, }} 10^{-7} \mathrm{~mol} / 1 \cdot \mathrm{s}$ & $\begin{array}{c}\mathrm{NO}_{2}^{-} \text {reduction, } \% \\
30 \mathrm{~min}\end{array}$ & $\begin{array}{c}{\left[\mathrm{NO}_{2}^{-}\right], 10^{-5} \mathrm{~mol} / \mathrm{l}} \\
30 \mathrm{~min}\end{array}$ \\
\hline 1 & 0,0 & 0,83 & 55,55 & 4,1 \\
\hline 2 & 1,0 & 3,17 & 87,97 & 1,3 \\
\hline 3 & 5,0 & 11,0 & 99,16 & 0,08 \\
\hline 4 & 10,0 & 13,83 & 100,0 & 0 \\
\hline
\end{tabular}

Based on the numeric curves, we calculated the speed constant (Fig. 4).

In Fig.4., there are presented the kinetic curves of nitrate consumption, depending on the $\mathrm{DFH}_{3} \mathrm{Na}$ concentration. The nitrite concentration reduces during 1 min from $100 \mu \mathrm{M}$ to $95 \mu \mathrm{M}, 84 \mu \mathrm{M}, 28 \mu \mathrm{M}, 8 \mu \mathrm{M}$, corresponding for $\mathrm{C}_{1}, \mathrm{C}_{2}$, $\mathrm{C}_{3}, \mathrm{C}_{4}$ concentrations of $\mathrm{DFH}_{3} \mathrm{Na}$.

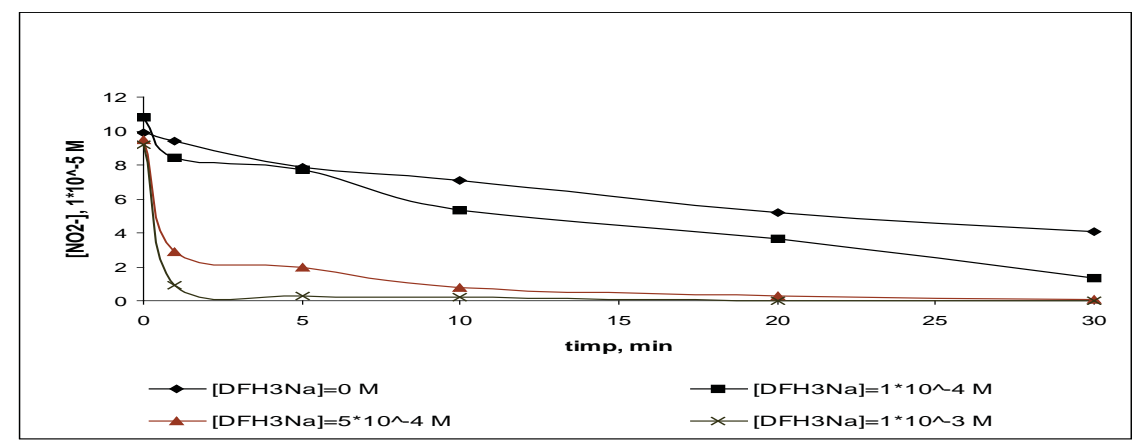

Fig. 4. The kinetic curves of nitrite consumption, depending on $\left[\mathrm{DFH}_{3} \mathrm{Na}\right]_{0},\left[\mathrm{NO}_{2}^{-}\right]_{0}=1 \cdot 10^{-4} \mathrm{~mol} / 1, \mathrm{pH} 2.6, \mathrm{t}=37^{\circ} \mathrm{C}$. 
If we increase $\mathrm{DFH}_{3} \mathrm{Na}$ concentration from $100 \mu \mathrm{M}$ to $1000 \mu \mathrm{M}, \mathrm{NO}_{2}{ }^{-}$concentration decreases from $95 \mu \mathrm{M}$ to 8 $\mu \mathrm{M}$, thus, we obtain the following: the augmentation of reducer concentration (10 times) leads to the decrease of $\mathrm{NO}_{2}^{-}$ concentration (almost 10 times). For $\mathrm{DFH}_{3} \mathrm{Na}$ concentration of $100 \mu \mathrm{M}$ the diminution of the nitrite content is slow, but when the $\left[\mathrm{DFH}_{3} \mathrm{Na}\right]$ increases the initial speed suddenly augments. The nitrite concentration reduces almost to 0 in 10 $\min$ for $\mathrm{C}^{3}{ }_{\text {DFHNa }}$ and in 1 min for $\mathrm{C}_{\text {DFHNa }}^{4}$ (the rapport $\left[\mathrm{DFH}_{3} \mathrm{Na}_{0}:\left[\mathrm{NO}_{2}^{-}\right]_{0}\right.$ for $\mathrm{C}_{\text {DFHNa }}^{3}$ is 5 , while for $\mathrm{C}_{\text {DFHNa }}^{4}$ it is 10). The higher the rapport, the greater the speed of the reaction. In the case when $\left[\mathrm{DFH}_{3} \mathrm{Na}\right]_{0}=0$, at $\mathrm{pH} 2,6$ (citrate phosphate solution buffer), in the system there takes place the nitrite transformation into other forms $\left(\mathrm{HNO}_{2}, \mathrm{NO}_{2} \mathrm{~N}_{2} \mathrm{O}_{3}, \mathrm{~N}_{2} \mathrm{O}_{4}\right.$, $\mathrm{NO}_{3}^{-}$), thus $\left[\mathrm{NO}_{2}^{-}\right]$reduces, which was determined by Griess method (kinetic curve for $\mathrm{C}^{1}{ }_{\mathrm{DFHNa}}=0$ ).

We also studied the kinetic of nitrite consumption in presence of dihydroxifumarole acid $\left(\mathrm{DFH}_{4}\right)$. The experimental conditions have been the same as in the case of usage as a $\mathrm{DFH}_{3} \mathrm{Na}$ reducer. The data concerning the nitrite consumption, obtained for different $\mathrm{DFH}_{4}$ concentrations have been inserted in Tab.2.

The effect of nitrite reduction with DFH4 at $\mathrm{pH} 2,6 ; \mathrm{t}=37^{\circ} \mathrm{C},\left[\mathrm{NO}_{2}^{-}\right]_{0}=1 \cdot 10^{-4} \mathrm{~mol} / \mathrm{l}$

\begin{tabular}{|c|c|c|c|c|}
\hline $\mathrm{Nr}$. & {$\left[\mathrm{DFH}_{4}\right]_{0}, 10^{-4}, \mathrm{M}$} & $\mathrm{W}_{\text {init, }}, 10^{-7} \mathrm{~mol} / \mathrm{l} \cdot \mathrm{s}$ & $\begin{array}{c}\mathrm{NO}_{2}^{-} \text {reduction, } \% \\
30 \mathrm{~min}\end{array}$ & $\begin{array}{c}{\left[\mathrm{NO}_{2}^{-}\right], 10^{-5} \mathrm{~mol} / 1} \\
30 \mathrm{~min}\end{array}$ \\
\hline 1 & 0,0 & 0,83 & 55,55 & 4,1 \\
\hline 2 & 1,0 & 10,25 & 89,74 & 1,0 \\
\hline 3 & 5,0 & 14,17 & 100,0 & 0 \\
\hline 4 & 10,0 & 14,65 & 100,0 & 0 \\
\hline
\end{tabular}

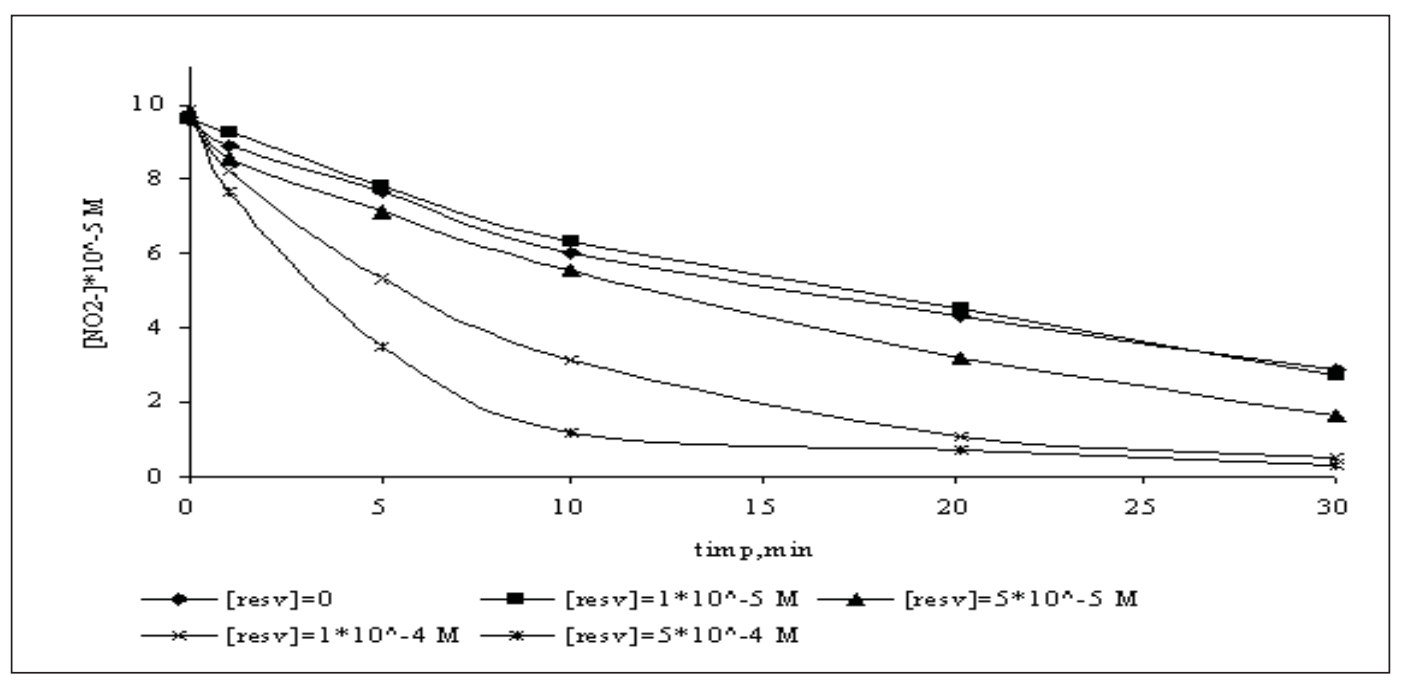

Fig.5. The kinetic curves of nitrite consumption depending on $[\mathrm{Resv}]_{0},\left[\mathrm{NO}_{2}^{-}\right]_{0}=1 \cdot 10^{-4} \mathrm{~mol} / 1, \mathrm{pH} 2.6, \mathrm{t}=37^{\circ} \mathrm{C}$.

In presence of $\mathrm{DFH}_{4}$, the nitrite concentration reduces with a higher speed, in comparison with $\mathrm{DFH}_{3} \mathrm{Na}$. From table 2 we can observe that at $\left[\mathrm{DFH}_{4}\right]_{0}=5 \cdot 10^{-4} \mathrm{~mol} / 1$, the degree of $\mathrm{NO}_{2}$ - transformation constitutes $100 \%$.

\section{Nitrite reduction with polyphenols}

In the present study we researched the influence of rezveratrol and $(+)$ catechine upon the process of nitrite reduction in the pattern sample.

One of the polyphenols, resveratrol (trans-3,5,4'-trihydroxystilben) (Resv), is a phytoalexine synthesized in certain plants, such as eucalyptus, spruce fir, lily. It is also tyo be found inmulberries and ground nuts, but the main natural source of Resv is Vitis Vinifera. It is synthesized as a response to fungi development in the grape-vine. The content of resveratrol in ground nuts varies from 0,02 to $1,79 \mu \mathrm{g} / \mathrm{g}$, and the peel of fresh grapes contains almost $50-200$ $\mu \mathrm{g} / \mathrm{g}$. A glass of red wine reaches between $600-700 \mu \mathrm{g}$ of Resv and has a beneficent effect upon the prophylaxis of heart diseases, leukaemia and cancer.

In the present work we studied the variation of nitrite concentration depending on the Resv concentration $\left(\mathrm{C}^{1}{ }_{\text {Rezv }}=\right.$ $0 \mathrm{M}, \mathrm{C}_{\text {Rezv }}^{2}=5 \cdot 10^{-5} \mathrm{M}, \mathrm{C}_{\text {Rezv }}^{3}=1 \cdot 10^{-4} \mathrm{M}, \mathrm{C}_{\text {Rezv }}^{4}=5 \cdot 10^{-4} \mathrm{M}, \mathrm{C}_{\text {Rezv }}^{5}=1 \cdot 10^{-3} \mathrm{M}$ ) la pH 2,6 (citrate phosphate solution buffer 
in the $\mathrm{NO}_{2}-$ Resv system). From the data presented in Fig.5, we observe that during 30 min the nitrite concentration reduces from $100 \mu \mathrm{M}$ to 0 for $\mathrm{C}^{3}{ }_{\text {Rezv }}, \mathrm{C}_{\text {Rezv }}^{4}$ and $\mathrm{C}_{\text {Rezv }}^{5}$. In the case of $\mathrm{C}_{\text {Rezv }}^{2}$ the nitrite concentration does not reduce up to 0 , because the reducer concentration is lower in comparison with the nitrite concentration $(50 \mu \mathrm{M}$ and $100 \mu \mathrm{M}$ accordingly). Thus, in the system we have a remnant concentration of nitrite after the whole Resv was consummated. In this system, the initial speed of transformation of nitrite $\left(\mathrm{W}_{\mathrm{NO}_{2}}\right)$ is lower than in the case of $\mathrm{DFH}_{3} \mathrm{Na}_{\text {or }} \mathrm{DFH}_{4}\left(\mathrm{Fig}_{\text {. }}\right.$. .) and it is comparable with $\mathrm{W}_{\mathrm{NO2}-}$ in $(+) \mathrm{Ct}$ presence.

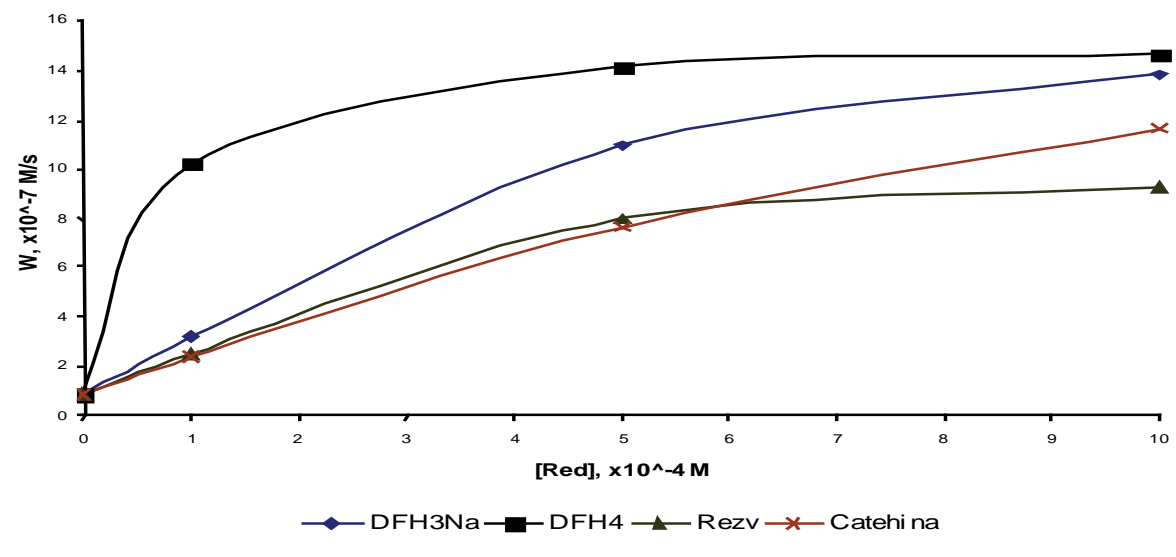

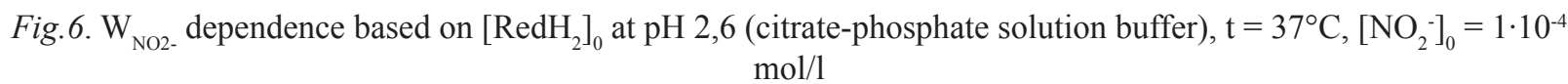

$\mathrm{PH}$ of the reaction medium plays a great importance in the process of interaction of Resv with $\mathrm{NO}_{2}$. This process was studied on different $\mathrm{pH}(1.0,2.6,3.0,3.6,4.0,6.0)$ for $\left[\mathrm{NO}_{2}^{-}\right]_{0}$ and $[\mathrm{Resv}]_{0}$ of $1 \cdot 10^{-4} \mathrm{~mol} / 1$, in citrate phosphate solution buffer. We established that $\mathrm{pH}$ decrease augments the speed of reaction between Resv and nitrite.

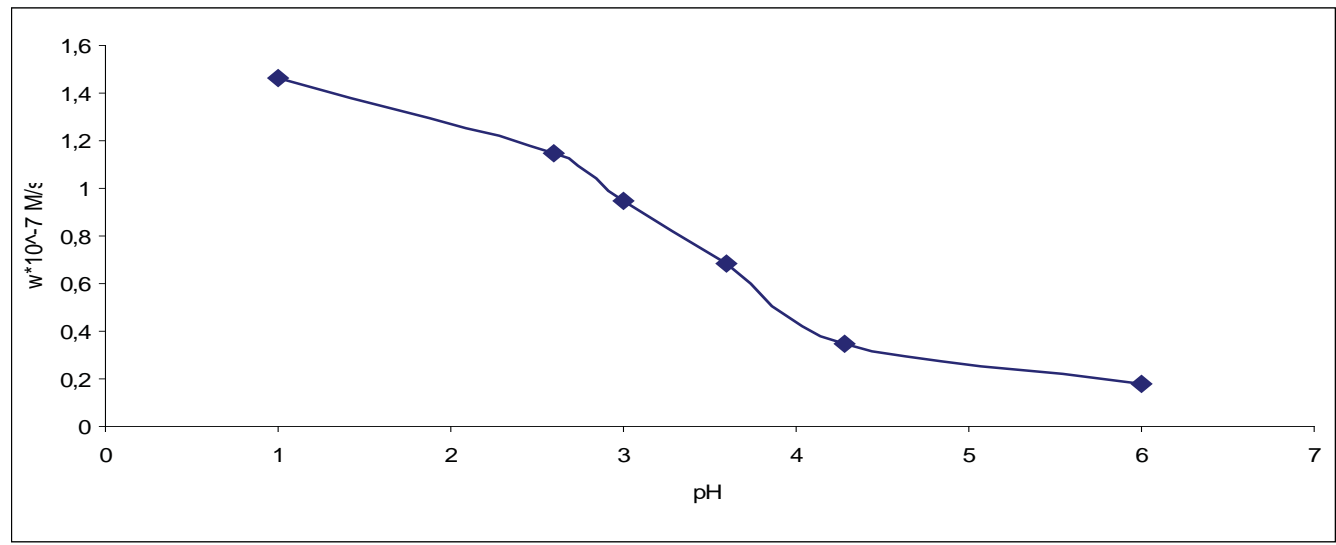

Fig. 7. The initial variation speed of nitrites, depending on the $\mathrm{pH}$ for $\left[\mathrm{NO}_{2}^{-}\right]_{0}=1 \cdot 10^{-4} \mathrm{~mol} / \mathrm{l},[\mathrm{Rezv}]_{0}=1 \cdot 10^{-4} \mathrm{~mol} / 1$ and $\mathrm{t}=37^{\circ}$

The nitrite concentration reduces for $\mathrm{pH} 1.0$ from $1 \cdot 10^{-4} \mathrm{~mol} / 1$ to $\sim 0,77 \cdot 10^{-4} \mathrm{M}$ (in $5 \mathrm{~min}$ ), i.e. with $53 \mu \mathrm{M}$, while at $\mathrm{pH} 3.0$ with $\sim 23 \mu \mathrm{M}$ (the same period of time). Thus, less nitrite is used in the reaction, in the case of an increased $\mathrm{pH}$. This may indicate that Resv is a less efficient inhibitor for an increased $\mathrm{pH}$, because when the $\mathrm{pH}$ augments, a bigger quantity of nitrites remains in the system. We measured the initial variation speed of nitrites, depending on $\mathrm{pH}$ and we established that $\mathrm{W}_{\mathrm{NO}_{2-}}$ decreases when $\mathrm{pH}$ increases (Fig.7).

Another inhibitor that was studied is $(+)$ catechine $((+) \mathrm{Ct})$. The data obtained from the experiences on the reduction of $\mathrm{NO}_{2}{ }^{-}$with $(+) \mathrm{Ct}$ are presented in Tab. 3 . 
The effect of nitrites reduction with $(+)$ catechine, $\mathrm{pH} 2.6, \mathrm{t}=37^{\circ} \mathrm{C},\left[\mathrm{NO}_{2}^{-}\right]_{0}=1 \cdot 10^{-4} \mathrm{~mol} / \mathrm{l}$

\begin{tabular}{|c|c|c|c|c|}
\hline Nr. & {$[(+) C t]_{0}, 10^{-4}, \mathrm{M}$} & $\mathrm{W}_{\text {init, }}, 10^{-7} \mathrm{~mol} / 1 \cdot \mathrm{s}$ & $\begin{array}{c}\text { Effect of reduction } \mathrm{NO}_{2}^{-}, \% \\
30 \mathrm{~min}\end{array}$ & $\begin{array}{c}{\left[\mathrm{NO}_{2}^{-}\right], 10^{-5} \mathrm{~mol} / 1} \\
30 \mathrm{~min}\end{array}$ \\
\hline 1 & 0,0 & 0,83 & 55,55 & 4,1 \\
\hline 2 & 1,0 & 2,33 & 98,33 & 0,15 \\
\hline 3 & 5,0 & 7,66 & 97,83 & 0,2 \\
\hline 4 & 10,0 & 11,67 & 99,5 & 0,05 \\
\hline
\end{tabular}

From the data presented in the table 3, we observe that the reduction speed of $\mathrm{NO}_{2}^{-}$increases simultaneously with the $(+) \mathrm{Ct}$ concentration. For $[(+) \mathrm{Ct}]=1 \cdot 10^{-3} \mathrm{~mol} / 1, \mathrm{NO}_{2}{ }^{-}$concentration reduces with $99,5 \%$. Thus, we can mark that $(+) \mathrm{Ct}$ reduces $\left[\mathrm{NO}_{2}^{-}\right]$when it interacts with $\mathrm{NO}_{2}^{-}$in the reactive medium.

\section{DISCUSSION}

\section{The variation of the concentration of nitrites in acid medium}

In the system nitrite - citrate phosphate buffer ( $\mathrm{pH} 2.6)$, the nitrite concentration decreases $\left(\left[\mathrm{RedH}_{2}\right]=0 \mathrm{M}\right)$. In this case, the quota of nitrites determined via Griess method, is almost 55\%. The decrease of the NO2 content in acid medium occurs in 2 ways: oxidation up to nitrates and the transformation into various volatile forms, agents of nitrosation. These forms are produced at the interaction of nitrite ions with the proton $\left(\mathrm{H}^{+}, \mathrm{H}_{3} \mathrm{O}^{+}\right)$, leading to the formation of nitrous acid. It has been demonstrated that the diminution of nitrite concentration is accelerated by $\mathrm{pH}$ reduction, and the effect of $\mathrm{pH}$ decrease leads to increase of $\mathrm{HNO}_{2}$ concentration from the system, thus, the equilibrium emerges to the augmentation of $\mathrm{NO}, \mathrm{NO}_{2}$ and $\mathrm{N}_{2} \mathrm{O}_{4}$ concentrations [20]:

$$
\begin{aligned}
& \mathrm{NO}_{2}^{-}+\mathrm{H}^{+} \stackrel{k_{1}}{\longrightarrow} \mathrm{HNO}_{2} \\
& 2 \mathrm{HNO}_{2} \leftrightarrow \mathrm{N}_{2} \mathrm{O}_{3}+\mathrm{H}_{2} \mathrm{O} \\
& \mathrm{N}_{2} \mathrm{O}_{3} \leftrightarrow \mathrm{NO}+\mathrm{NO}_{2} \\
& 2 \mathrm{NO}_{2} \leftrightarrow \mathrm{N}_{2} \mathrm{O}_{4} \\
& \mathrm{~N}_{2} \mathrm{O}_{4}+\mathrm{H}_{2} \mathrm{O} \rightarrow 2 \mathrm{H}^{+}+\mathrm{NO}_{2}^{-}+\mathrm{NO}_{3}^{-}
\end{aligned}
$$

Aerobian conditions:

$$
2 \mathrm{NO}+\mathrm{O}_{2} \rightarrow \mathrm{N}_{2} \mathrm{O}_{4}
$$

Open system:

$$
\begin{aligned}
& \mathrm{NO}(\mathrm{aq}) \leftrightarrow \mathrm{NO}(\mathrm{g}) \\
& \mathrm{NO}_{2}(\mathrm{aq}) \leftrightarrow \mathrm{NO}_{2}(\mathrm{~g}) \\
& \mathrm{O}_{2}(\mathrm{aq}) \leftrightarrow \mathrm{O}_{2}(\mathrm{~g})
\end{aligned}
$$

The main agents of nitrosation that form are $\mathrm{N}_{2} \mathrm{O}_{3}, \mathrm{~N}_{2} \mathrm{O}_{4}$, and $\mathrm{NO}_{2}$. At moderate acidity ( $\mathrm{pH} 2$-5) all these agents are present in the reaction medium and are detected by [21], through spectrophotometric methods. At $\mathrm{pH}<2$ the closest agent is $\mathrm{H}_{2} \mathrm{O}^{+} \mathrm{NO}$, which predominates in system $\left(\mathrm{HNO}_{2}+\mathrm{H}^{+} \leftrightarrow \mathrm{H}_{2} \mathrm{O}^{+} \mathrm{NO}\right)$. The speed for nitrite transformation depends on the initial concentration of $\mathrm{NO}_{2}^{-}$, while the speed for its decreasing is determined by the equation [20]:

$$
\mathrm{W}=1,1 \mathrm{k}_{1} \mathrm{a}[\mathrm{NO}]+0,9 \mathrm{k}_{\mathrm{L}} \mathrm{a}\left[\mathrm{NO}_{2}^{-}\right]+\mathrm{k}_{5}\left[\mathrm{~N}_{2} \mathrm{O}_{4}\right]
$$

At the introduction of $\mathrm{SCN}^{-}$and $\mathrm{Cl}^{-}$ions into the system, the speed of nitrite variation augments, because new formed species direct the equilibrium towards right: 


$$
\begin{aligned}
& \mathrm{HNO}_{2}+\mathrm{H}^{+} \leftrightarrow \mathrm{NO}^{+}+\mathrm{H}_{2} \mathrm{O} \\
& \mathrm{NO}^{+}+\mathrm{SCN}^{-} \leftrightarrow \mathrm{NOSCN} \\
& \mathrm{NO}^{+}+\mathrm{Cl}^{-} \leftrightarrow \mathrm{NOCl}
\end{aligned}
$$

In citrate-phosphate solution buffer, the concentration of the nitrites reduces from $1 \cdot 10^{-4} \mathrm{~mol} / 1$ to $1.5 \cdot 10^{-4} \mathrm{~mol} / 1$, while in presence of $\mathrm{SCN}^{-}$and $\mathrm{Cl}^{-}$ions, the variation of nitrite concentration reduces from $0.4 \cdot 10^{-4} \mathrm{~mol} / 1$ to $0.3 \cdot 10^{-4}$ $\mathrm{mol} / \mathrm{l}$ and .....accordingly.

The speed for nitrite transformation is greater in presence of $\mathrm{SCN}^{-}$ions. The speed constant for the reaction (16) $\left(\mathrm{k}_{10.2}=3,4 \cdot 10^{9} \mathrm{M}^{-1} \mathrm{~s}^{-1}\right)$ is pretty high and thus, the speed of $\mathrm{NO}_{2}^{-}$concentration variation is greater than in presence of $\mathrm{Cl}^{-}$ions with $\mathrm{NOCl}$ formation (reaction 17).

The influence of $\mathrm{SCN}^{-}$ions upon the speed of $\mathrm{NO}_{2}^{-}$transformation is determined by $\mathrm{pH}$ of the medium. The concentration of NOSCN complex decreases when $\mathrm{pH}$ (the interval 1.0-3.5) increases, because of the simultaneous reduction of $\left[\mathrm{NO}^{+}\right]$.

\section{The interaction of the reducers with the nitrites}

The substrate interact cu nitric trioxide (III), formed from the nitrous acid obtained after the reaction (7). The reaction speed is of $2^{\text {nd }}$ order after the concentration of the nitrite and of $1^{\text {st }}$ order after the substrate concentration:

$$
\begin{aligned}
& \mathrm{N}_{2} \mathrm{O}_{3}+\mathrm{S} \stackrel{k_{\mathrm{B}}}{\longrightarrow} \mathrm{S}^{+}-\mathrm{NO}+\mathrm{NO}_{2}^{-} \\
& \mathrm{W}=\mathrm{k}_{18}\left[\mathrm{~N}_{2} \mathrm{O}_{3}\right][\mathrm{S}]=\mathrm{k}_{18} \mathrm{k}_{6}\left[\mathrm{HNO}_{2}\right]^{2}[\mathrm{~S}]
\end{aligned}
$$

In the case when there are huge concentrations of substrate, the speed of the reaction can be represented via 2 nd order after the nitrite and zero after the substrate:

$$
\mathrm{W}=\mathrm{k}^{\prime}\left[\mathrm{HNO}_{2}\right]^{2}
$$

In the system of reaction, $\mathrm{DFH}_{4}$ acid and $\mathrm{DFH}_{3} \mathrm{Na}$ interact cu the formed species (at $\mathrm{pH}$ of $2,6, \mathrm{~N}_{2} \mathrm{O}_{3}$ predominates) and thus, there takes place the reduction of concentration of nitrosation agents.

$$
\begin{aligned}
& \mathrm{RedH}_{2}+\mathrm{H}^{+}+\mathrm{NO}_{2}{ }^{-} \rightarrow \mathrm{RedH}^{\cdot}+\mathrm{H}_{2} \mathrm{O}+\mathrm{NO} \\
& \mathrm{RedH} \cdot+\mathrm{H}_{2} \mathrm{O}+\mathrm{NO}+\mathrm{H}^{+}+\mathrm{NO}_{2}-\rightarrow \mathrm{Red}+2 \mathrm{NO}+2 \mathrm{H}_{2} \mathrm{O}
\end{aligned}
$$

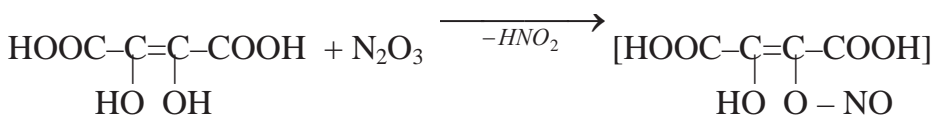

$$
\begin{aligned}
& \rightarrow \text { HOOC-C }=\mathrm{C}-\mathrm{COOH} \stackrel{-2 N O}{\mathrm{HOOC}-\mathrm{C}-\mathrm{C}-\mathrm{COOH}}
\end{aligned}
$$

The nitrite reducers indicate that the nitrite concentration in the system reduces when their concentration increases. We used $(+)$ catechine and resveratrol to perform the researches (Fig.8.)<smiles>Oc1ccc(C=Cc2cc(O)cc(O)c2)cc1</smiles>

Fig. 8. The chemical structure of the resveratrol 
In presence of $\mathrm{SCN}^{-}$and $\mathrm{Cl}^{-}$ions, the reducers interact with the nitrosyl $\mathrm{NOSCN}$ and $\mathrm{NOCl}$ species formed during the reaction (15) and (16), or with other species:

$$
\mathrm{RedH}_{2}+\mathrm{NOX} \rightarrow \mathrm{HNO}_{2}+\mathrm{Red}+2 \mathrm{NO}+\mathrm{HX}+\mathrm{H}_{2} \mathrm{O}
$$

In the equation (23), NOX represents $\mathrm{N}_{2} \mathrm{O}_{3}, \mathrm{NO}^{+}, \mathrm{NOSCN}$, or NOCl. In presence of nitrosyl species, due to the catalytic effect, the nitrite consumption is greater, if compared with the system where there is only $\mathrm{ClO}_{4}^{-}$or citratephosphate solution buffer.

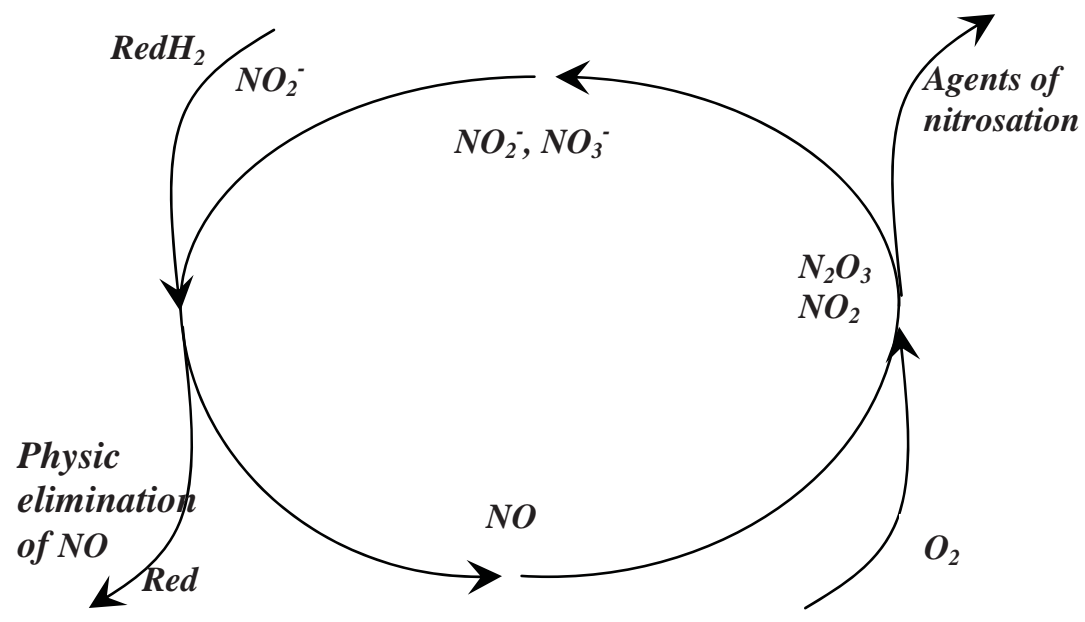

Fig. 9. Cycle of transformation of the nitrites in presence of $\mathrm{RedH}_{2}$ (aerobian conditions).

This indicates that in presence of $\mathrm{SCN}^{-}$, the reducers can become less effective inhibitors in various processes of nitrosation. The $\mathrm{SCN}^{-}$ion is a stronger catalyst than $\mathrm{Cl}^{-}$, this could be explained by the different equilibrium constants of the reaction (16) and (17).

As a result of the interaction of the reducers with different agents of nitrosation, the nitrite oxidation state changes, by reducing up to $\mathrm{NO}$ or oxidising up to $\mathrm{NO}_{3}^{-}[20]$. The reduction of the nitrite concentration in the system during the reaction under the $\mathrm{DFH}_{3} \mathrm{Na}$ or $\mathrm{DFH}_{4}$ action is determined by the speed of transformation of $\mathrm{NO}_{2}$ - into $\mathrm{NO}^{-}$which further, in the gas phase, is removed. The nitric oxide, formed in aerobian conditions, can be recycled into agent of nitrosation or can be removed via mass transfer. The reduced speed of the mass transfer of NO reduces the inhibitory efficacy of the reducers, because in this case, due to the formation of a cycle, more $\mathrm{RedH}_{2}$ inhibitor is consumed (Fig. 9).

In aerobian conditions, the reaction (11), that leads to the formation of $\mathrm{Na}_{2} \mathrm{O}_{4}$, will not take place, thus, the $\mathrm{NO}_{2}^{-}$ concentration, that transforms after the reactions (6) and (7) into nitrosation agents, will decrease.

As a result of the study of the process of interaction between $\mathrm{NO}_{2}^{-}$and $\mathrm{DFH}_{4}$ in aerobian and anaerobic conditions we established that the speed for $\mathrm{NO}_{2}{ }^{-}$diminution is greater, in absence of the oxygen. In this case, less $\mathrm{DFH}_{4}$ is being consumed for the reduction of nitrite at their initial concentration and in the system; the concentration of nitrite reduces considerably.

The increase of the reaction speed simultaneously with $\mathrm{pH}$ reduction from 6,0 to 1,0 in $\mathrm{Rezv}-\mathrm{NO}_{2}{ }^{-}$system is determined by the deviations of the equilibrium, depending on $\mathrm{pH}$ in equations (6) and (7) more towards right, thus, in the system, $\mathrm{NO}_{2}{ }^{-}$concentration decreases. But in this case, the stoichiometric rapport of the reducers consumed for the nitrite removal will increase.

From fig. 5 we can observe that at $\mathrm{pH} 1.0$ the speed of $\mathrm{NO}_{2}^{-} \mathrm{d}$ concentration is maximum and decreases while $\mathrm{pH}$ increases, in the established interval (almost 10 times) In aerobian conditions, the quantity of reducers that will be spent to remove the nitrite will be determined on one hand, by the rivalry between NO recycling and its transformation into nitrosation agent, and the removal of NO via mass transfer, on the other hand.

In conclusions, we may state that the degree of nitrite diminution in the $\mathrm{RedH}_{2}-\mathrm{NO}_{2}^{-}$system decreases in the following manner: $\mathrm{DFH}_{4}<\mathrm{DFH}_{3} \mathrm{Na}<\mathrm{Resv}<(+) \mathrm{Ct}$.

\section{REFERENCES}

[1] Jung F., Lassman G., Ebert B., Studiu Biophys.- 1981. - Vol.85. - V2. - p.139-140.

[2] KosakaH.,UozumM., Biochem.Biophys. Acta. - 1986. - Vol. 871. - N1., p.14-18.

[3] Tomoda A., Tsuji A., Yoneuama G. Biochem.J.- 1981. - Vol. 193. - N1. - p. 169-179. 
[5] Shugaley I.V., Lopatina N.I., Umenskii I.V. Kinetics and mechanism of chain borning in the reaction of oxihemoglobin oxidation by nitrit. JOCh. - 1990. - T.60. - vol. 7. - c. 1650-1652.

[6] Navindra P. Seeram, Yanjun Zhang, and Muraleedharan G. Nair, Inhibition of Proliferation of Human Cancer Cells and Cyclooxygenase Enzymes by Anthocyanidins and Catechins, Nutrition and Cancer, 2003, 46(1), 101106.

[7] Cecilia Matito, Foteini Mastorakou, Josep J. Centelles, Josep L. Torres, Marta Cascante, Antiproliferative effect of antioxidant polyphenols from grape in murine Hepa-1c1c7 Eur J Nutr 42 : 43-49, 2003, DOI 10.1007/s00394003-0398-2.

[8] Brownson D.M., Arios N.G., Fugua B.K., Dnarmawardhane S.F., Mabry T.J., Flavonoid effects relevant to cancer, J.Nutr., Nov.1, 2002, 132(11): 3482S-4389.

[9] .Kyrtopoulos S.A, Pignatelli B., Kakanais G., Golematis B. and Esteve J.,,Studies of gastric carcinogenesis. V. The effects of ascorbic acid on N-nitroso compound formation in human gastric juice in vivo and in vitro ", Carcinogenesis, 1991, vol.12 no.8 pp.1371 - 1376.

[10] Martırnezy C. Jimernez, Loarca-Pinaz G. and Dar vila Ortırzy G. Antimutagenic activity of phenolic compounds, oligosaccharides and quinolizidinic alkaloids from Lupinus campestris seeds, Food Additives and Contaminants, Vol. 20, No. 10 (October 2003), pp. 940-948 (Received 10 March 2003; revised 20 June 2003; accepted 14 July 2003).

[11] Rice-Evans C.A., Miller N.J., Paganga G., Structure-antioxidant activity relationships of flavonoids and phenolic acids, Free Rad. Biol \& Medecine, vol.20, No.7, 1996, 933-955.

[12] Anderson R..E., Fisher L.J., Hara Y., Harris T., Mak W.B., Melton L.D., Pacher J.E., Green catechins partially protect DNA from $\mathrm{OH}^{*}$ radical-induced strand breaks and base damage through fast chemical repair of DNA radicals, Carcinogenesis, vol.22, no.8, 2001, 1189-1193.

[13] Lopez-Burillo S., Tan D.-X., Mayo J.C., Sainz Rosa M., Manchester L.C. and Reiter R.J., Melatonin, xanthurenic acid, resveratrol, EGCG, vitamin $\mathrm{C}$ and a-lipoic acid differentially reduce oxidative DNA damage induced by Fenton reagents: a study of their individual and synergistic actions J. Pineal Res. 2003; 34:269-277.

[14] Chung S. Yang, Pins Maliakal, Xiaofeng Meng, Inhibition of carcinogenesis by TEA, Annu.Rev,Pharmacol. Toxicol., 2000, 42:25-54.

[15] Yamamotoa Y., Matsunaga K. and Friedman H., Protective effects of green tea catechins on alveolar macrophages against bacterial infections, BioFactors 21 (2004) 119-121 119.

[16] Duca Gh., Gonța M., Matveevici V., Iambarțev V. Impact des nitrites, nitrates et N-nitrosamines sur la sante et leur contenu dans les produits carnes // Actes du seminaire d'animation regionale (Region Europe Centrale et Occidentale SAR-2004). Chisinau: “Tehnica-Info". - 12-14 mai, 2004.- p. 43-48.

[17] Shugalei I.V., Lopashina N.I., Tzelinskii I.V., JOCh., 1988. Vol.58, 4 ed., p. 886-890.

[18] Mirvish S.S., Nitrate and nintrite concentration in human saliva for men and women at different ages and time of the day and their consistency over time, Eur. J. Of Cancer Prev., 2000, vol.9, p. 335-342.

[19] Gonța M. Inhibition of hemoglobin oxidation process in the presence of hydrogen peroxide, Mat. Conf. "Balance of scientific activity of USM, 2000-2002",Chişinău, 2003, p.70-71.

[20] Duca Gh., Gonța M. Impact of environment and methemoglobinemia, Mat. Conf. Scientific-practice, 2000, Chişinău: C.E.P Ştiinţa:2000, p.186-188.

[21] Lincht W.R., Tannenbaum S.R., Deen W.M., Use of ascorbic acid to inhibit nitrosation: kinetic and mass transfer considerations for an in vitro system, Carcinogenesis, Vol.9., 1988, 365-37. 